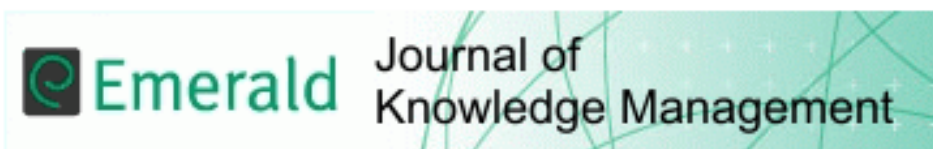

\section{Information technology-enabled explorative learning and competitive performance in industrial service SMEs: a configurational analysis}

\begin{tabular}{|r|l|}
\hline Journal: & Journal of Knowledge Management \\
\hline Manuscript ID & Draft \\
\hline Manuscript Type: & Research Paper \\
\hline Keywords: & $\begin{array}{l}\text { Explorative learning, IT capabilities, Strategic capabilities, Capability } \\
\text { configuration, Competitive performance, fsQCA }\end{array}$ \\
\hline \multicolumn{2}{|l}{} \\
\hline
\end{tabular}

\section{SCHOLARONE \\ Manuscripts}




\title{
Information technology-enabled explorative learning and competitive performance in industrial service SMEs: a configurational analysis
}

\begin{abstract}
Purpose As purveyors of knowledge-based and high value-added services to the manufacturing sector, industrial service SMEs must develop the information technology (IT) capabilities that, in combination with other non-IT capabilities, enable their capacity for organizational learning (OL), and for explorative learning in particular. In this context, we aim to identify the different causal configurations that account for the nonlinear complex interplay of IT capabilities for exploration and strategic capabilities for explorative learning as they affect competitive these firms' competitive performance.
\end{abstract}

Design/methodology/approach Survey data obtained from 92 industrial service SMEs were analysed with a configurational approach, using fuzzy set qualitative comparative analysis (fsQCA).

Findings As it allows for equifinality, the fsQCA analysis identified six causal configurations that characterize the sampled firms' explorative learning capability, two being equally associated with high innovation performance, and four being equally associated with high productivity.

Originality/value By viewing explorative learning as a dynamic capability that is enabled by the firm's IT and strategic capabilities, our study contributes to OL theory by providing a more concrete or 'operational' grounding which allows for a greater practical applicability of this theory. By taking both the configurational and capability-based views of the OL-ITperformance causal framework, we provide an empirical basis for unraveling, explaining and understanding the complex non-linear relationships embedded within this framework.

Keywords: Explorative learning, IT capabilities, Strategic capabilities, Capability configuration, Competitive performance, fsQCA, Industrial service, SME

Paper type Research paper

\section{Introduction}

In a digital world that has shifted from a product-based to a knowledge-based global economy, and where the frontier between product and service is now blurred, one of the most important issues for strategic management, small business, and information systems (IS) researchers and 
practitioners lies in identifying the effects of the firm's information technology (IT) resources and competencies that, in combination with other non-IT resources and competencies, enable its capacity for organizational learning (OL) (Andreu and Ciborra, 1996; Janson, CecezKecmanovic and Zupančič, 2007; Kane and Alavi, 2007; Real, Leal and Roldán, 2006). As purveyors of knowledge-based, high value-added services to the manufacturing sector (Bryson, Keeble and Wood, 1997), industrial service firms, most of whom are small and medium-sized enterprises (SMEs), must answer a dual management challenge. That is, they are challenged to respond to both the digitalization and the globalization of their business environment by formulating and implementing a digital transformation strategy (Bharadwaj, El Sawy, Pavlou and Venkatraman 2013; Setia, Venkatesh and Joglekar, 2013). The strategic management and use of IT by these firms is thus meant to enable their learning processes and support their learning mechanisms (Andreu and Ciborra, 1996; Kane and Alavi, 2007; Nguyen, Ngo, Northey and Siaw, 2019). In doing so, the aim of the management and use of IT is also to maintain or improve firms' competitive performance in terms of innovation and productivity (Aboal and Tacsir, 2018; Soto-Acosta, Popa and Martinez-Conesa, 2018).

Researchers have studied OL processes under two forms, namely exploration and exploitation (March, 1991; Pentland, 1995). From a functionalist perspective in which 'OL is a synonym of information processing within organizations' (Popova-Nowak and Cseh, 2015, p. 305), explorative learning essentially refers to the firm's acquisition of new knowledge or replacement of existing knowledge in its organizational memory, whereas exploitative learning refers to the firm's reuse, diffusion and refinement of its existing knowledge (Kane and Alavi, 2007; Li and Huang, 2013; Nielsen, Mathiassen and Hansen, 2018). We focus on the first form in this study, as being most conducive to achieve high levels of competitive performance in the highly dynamic, turbulent and uncertain environment in which most industrial service SMEs 
operate (Bnner and Tushman, 2003; Dixon, Meyer and Day, 2007; Teece, Peterhaf and Leih, 2016).

The role and impact of IT with regards to OL processes and outcomes have been the object of some studies in the last twenty-five years (Robey, Boudreau and Rose, 2000). This includes, for instance, studies of IT-based OL support systems (Hine and Goul, 1998), of IT's role in the firm's organizational memory and learning (Croasdell, 2001), of IT-enabled explorative and exploitative learning mechanisms (Kane and Alavi, 2007), of IT-enabled OL in Web-based processes such as crowdsourcing (Schlagwein and Bjørn-Andersen, 2014), and of the impact of enterprise social media on OL (Qi and Chau, 2018). To-date, however, no attempts have been made to explain the complex interplay of the firm's IT capabilities with its other (non-IT) organizational capabilities in enabling its explorative learning process and thus improving its competitive performance, and especially in a SME context where the firm's IT resources and competencies have been found to play a strategic role in this regard (Raymond, Bergeron, Croteau and St-Pierre, 2016).

From a capability-based view of the firm's digital transformation (Easterby-Smith and Prieto, 2008), we focus here on its explorative learning capability, that is, on the firm's IT capabilities for exploration, on its strategic capabilities for explorative learning, and on the extent to which and manner by which these capabilities, in combination, enable firms to attain high levels of competitive performance (in terms of innovation and productivity). In characterizing, contextualizing and valuing the explorative learning capability, we take a 'configurational' approach that is grounded in contingency theory instead of the traditional universalistic or 'best practices' approach (Doty, Glick and Huber, 1993). Furthermore, by identifying the 'capability configurations' of industrial service enterprises (Miller, Eisenstat and Foote, 2002), we allow for complex and nonlinear relationships as well as for 'equifinality', or the possibility for industrial service firms to achieve high levels of competitive performance 
through different explorative learning paths and from different starting positions in terms of their IT and non-IT resources and competencies (Gresov and Drazin, 1997). This approach also allows for 'causal asymmetry', that is, the possibility that the capability configurations associated to high levels of competitive performance differ from the configurations associated to the absence of such performance (Fiss, 2011).

As applied here, the configurational approach is based on the premise that there are specific combinations of the firm's IT and non-IT capabilities that enable its explorative learning processes and, in turn, positively influence its competitive performance (Fiss, 2011). Therefore, the first research question to be answered by this study is the following: In the context of industrial service SMEs, what are the different explorative leaning capability configurations that lead to high levels of competitive performance? And given that the configurational approach allows for causal asymmetry, the second question follows: What are the capability configurations that prevent these firms from attaining high levels of competitive performance?

In answering these questions through an empirical study of 92 Canadian SMEs operating in the industrial services sector, we hope to provide deeper understanding of the nature and effects of the complex interplay between the firm's explorative learning and IT capabilities in this context. We also hope to fill the gap in the OL, small business and IT literatures in this regard, as our study's research contribution is threefold. First, by focusing specifically on explorative learning rather than organizational learning in general, we bring greater explicitness, precision and applicability to OL theory. Second, by taking a configurational rather than a 'best practices' approach, we bring greater validity, explanatory power and generalizability to OL theory. Third, by focusing on the specificities of SMEs with regard to OL and IT, we bring greater contextualization and theoretical relevance to our findings and thus better delineate our contribution to OL, small business and IT research and practice from that of previous empirical studies. 


\section{Theoretical and empirical background,}

Strategic management researchers have looked extensively at the firm's strategic capabilities to explain its organizational performance. These capabilities are defined as skill sets and knowledge ensembles that enable the firm to deploy its assets and coordinate its activities (Desarbo, Di Benedetto, Song and Sinha, 2005). Thus, strategic capabilities have been found to determine critical organizational outcomes such as the firm's innovation performance (e.g. Di Benedetto, DeSarbo and Song, 2008) and productivity (e.g. Fabi, Lacoursière, Raymond and St-Pierre, 2010). In this regard however, most studies have taken a 'universalistic' perspective (Delery and Doty, 1996), assuming that the development of certain strategic capabilities constitute 'best practices' in such matters as R\&D (e.g. Beise-Zee and Rammer, 2006), networking (e.g. Ulubasoglu, Akdis and Kök, 2009), HR management (e.g. Hassid and Fafaliou, 2006) and IT management (e.g. Liu, Ke, Wei and Hua, 2013).

The universalistic perspective is deemed however to be insufficient by those researchers who rather take a 'configurational' perspective (Raymond and St-Pierre, 2013). From a holistic view of the firm as an 'open system', these researchers focus on strategic capability profiles or patterns rather than individual capabilities, that is, considering ensembles of variables that determine an outcome interdependently rather than individual variables independently of one another (Fiss, 2007). The firm may thus both attain and sustain a competitive advantage by developing a unique capability configuration, that is, by creating a coherent combination of strategic capabilities that is difficult to imitate by its competitors (Miller, Eisenstat and Foote, 2002).

As presented in Figure 1, explorative learning is viewed in this study through the 'capability-based' theoretical lens (Grant, 1996; Teece, Pisano and Shuen, 1997), that is, as a 'dynamic capability' that enables the firm to reconfigure its IT and non-IT resources and competencies in response to changing environmental contingencies (Pavlou and El Sawy, 
2011). We thus wish to contribute to OL theory by integrating concepts and insights obtained from the configurational approach, from the capability-based view (CBV), and from the strategic management, small business and IT literatures (Berta, Cranley, Dearing, Dogherty, Squires and Estabrooks, 2015). We also wish to contribute to OL practice as it is enabled by the strategic management and use of IT in an industrial service SME context.

\section{Figure 1: Dynamic capability-based view of explorative learning}

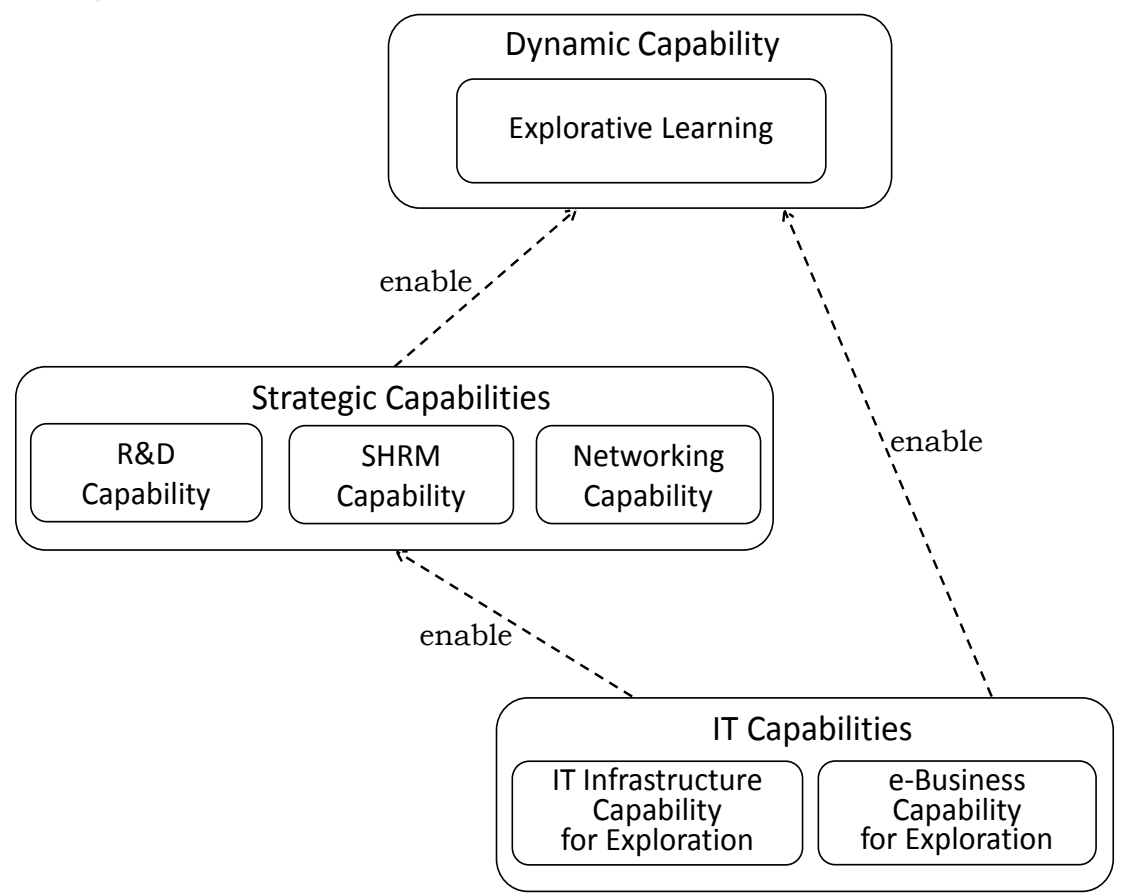

In taking the CBV to tackle our research questions, we initially propose that competitive performance, that is, innovation performance and productivity depend on specific configurations of three elements that, together, compose the industrial service SMEs' explorative learning capability. We define a configuration as a specific combination of elements - in this case, IT capabilities for exploration, strategic capabilities for explorative learning, and organizational size as the contextual contingency - that together generate the outcome of interest - in this case, competitive performance. This proposition leads us to empirically explore a research model that is based on the configurational approach, as presented in Figure 2, and as further explained below. 


\section{Figure 2: Research model on industrial service SMEs' explorative learning capability}

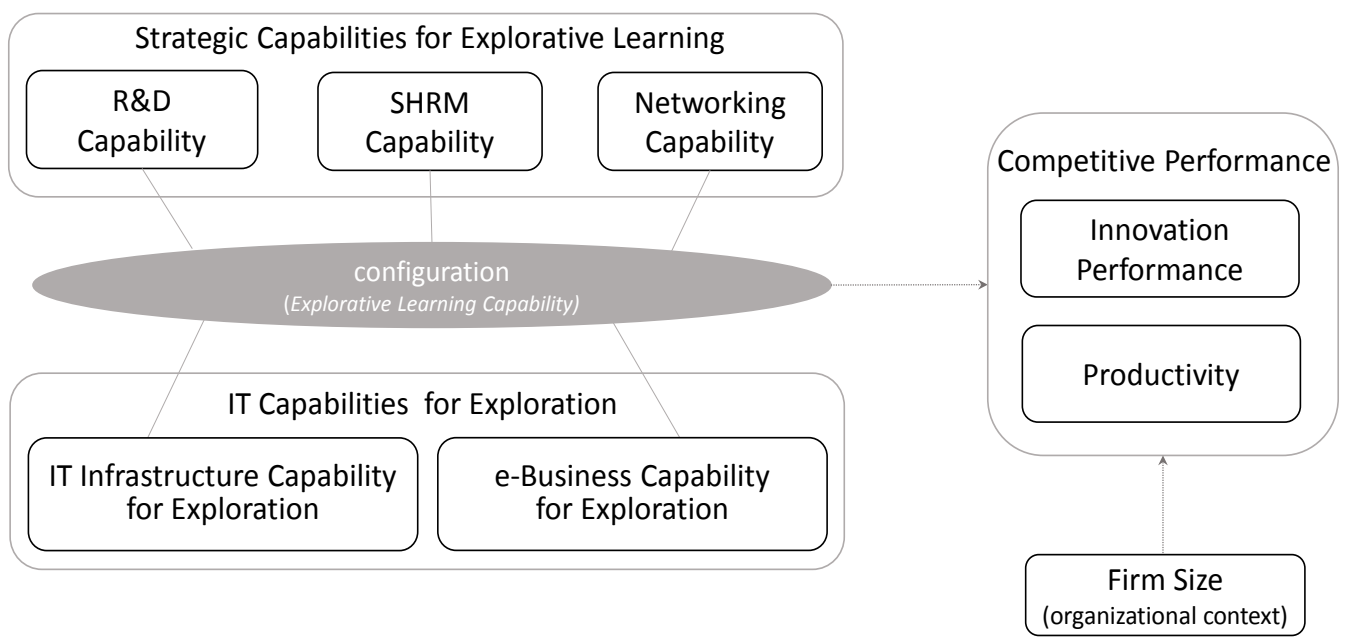

\subsection{IT capabilities for exploration}

IT capabilities are defined herein as the organization's ability to 'mobilize and deploy IT-based resources in combination or co-present with other resources and capabilities' (Bharadway, 2000, p. 171).

\subsubsection{IT infrastructure capability for exploration}

The firm's IT capabilities first include its IT assets such as the computing technologies and applications platform that constitute its 'IT infrastructure' (Ajamieh, Benitez, Braojos and Gelhard, 2016; Ross, 2003). Now, in view of the firm's strategic IT priorities with regard to developing its learning capability and absorptive capacity (Sun and Anderson, 2010; Zahra and George, 2002), certain IT infrastructure capabilities may be categorized as being either mainly explorative or exploitative through the notion of 'IT ambidexterity' (Lee, Sambamurthy, Lim and Wei, 2015), in line with Levinthal and March's (1993) conceptualization of how firms pursue either exploration or exploitation. For instance, certain technologies such as CAD/CAM mainly focus on product or service innovation, while others such as an ERP focus on improving efficiency within the firm (Aral and Weil, 2007). Therefore, CAD/CAM technologies are 
essentially explorative IT in nature, while ERP systems qualify as mainly exploitative IT. In this study however, we exclude exploitative IT, concentrating instead on explorative IT as these last technologies are the ones that are specifically designed to enable the firm's explorative learning processes (Lee and Widener, 2016) and to provide it with greater agility (Park, El Sawy and Fiss, 2017) in the face of increased competitive pressures.

\subsection{2 e-Business capability for exploration}

Organizational IT capabilities also include the IT competencies that allow a firm to enable its business processes as well as its knowledge management through its use of IT (Joshi, Chi, Datta and Han, 2010), that is, through its 'e-business' capabilities (Zhu, 2004). Now, in similar fashion to its IT infrastructure capabilities and again referring to the IT ambidexterity notion (Lee et al., 2015), the firm's e-business capabilities may be categorized as being either explorative or exploitative. For instance, certain forms of e-business such as e-collaboration and e-business intelligence are mainly explorative in nature as they focus on rendering the firm more agile and more innovative (Hill and Scott, 2004; Prajogo and Olhager, 2012), while others such as e-commerce are mainly exploitative in that they focus on enabling the firm's business processes and operations (Raymond and Blili, 2000; Zhu, 2004).

\subsection{Strategic capabilities for explorative learning}

Recalling that the firm's strategic capabilities have been found to shape its competitive performance (e.g. Hutton and Eldridge, 2019; Uwizeyemungu, Raymond, Poba-Nzaou and StPierre, 2018), three such capabilities, namely research and development (R\&D), strategic human resource management (SHRM) and networking capabilities were chosen on the basis of their being identified in the literature as enabling factors of explorative learning (Human and Naudé, 2009; Khatri, 2006; Martínez-Senra, Quintás, Sartal and Vázquez, 2015), and as being paramount for the competitive performance of SMEs in a globalized economy (Kroon, Van De Voorde and Timmers, 2013; Mu and Di Benedetto, 2012; Raymond and St-Pierre, 2013). 
Moreover, these capabilities are envisioned here as 'lower-order' capabilities embedded in the 'higher-order' explorative learning capability, such capability embeddedness being 'created by the combination of resources across functions and hierarchical levels within the firm' (Grewal and Slotegraaf, 2007, p. 455).

\subsubsection{R\&D capability}

In the industrial services sector, the R\&D capability refers to the firm's ability to acquire, assimilate, transform and exploit new knowledge, in conjunction with its human and intellectual capital and knowledge management competencies, in order to develop new services (service R\&D) or improve the process by which existing services are rendered to manufacturing firms (process R\&D) (Koschatsky and Stahlecker, 2010; Nunes, Serrasqueiro, Mendes and Sequeira, 2010). Moreover, the firm's R\&D capability may by itself constitute or be part of - its service offering (Un and Rodríguez, 2018). Now, this capability may also be considered as a proxy for the 'learning' dimension of the firm's absorptive capacity (Lucena and Roper, 2016). In empirical research, the R\&D capability has been observed to enable explorative learning processes (von Zedtwitz, 2002; Bresman, 2013; Un and Rodríguez, 2018). Likewise, researchers have found the R\&D capability to be a determinant of explorative learning (Belderbos, 2003; Martínez-Senra et al., 2015; Khedhaouria, Montani and Thurik, 2017). Furthermore, the firm's R\&D capability may be enabled by its IT capabilities, and especially by an e-business capability such as 'e-business intelligence' (Fink, Yogev and Even, 2017).

\subsubsection{SHRM capability}

The SHRM capability is defined as the firm's capacity to develop, motivate and empower human resources in order to meet strategic goals in a dynamic, turbulent and sometimes hostile environment (Khatri, Baveja, Agrawal and Brown, 2010). In empirical research, the OL capability has been found to interact with the SHRM capability in determining the performance 
of the HR function (Bhatnagar, 2007; Camps, Oltra, Aldás-Manzano, Buenaventura-Vera and Torres-Carballo, 2016) and to be positively impacted by certain SHRM practices such as talent management (Oltra and Vivas-López, 2013; Hu, Wu and Shi, 2016). The SHRM capability is considered to be the most critical of the strategic capabilities with regard to OL and is enabled by the IT infrastructural capabilities of the firm (Uwizeyemungu et al., 2018), and especially by an e-business capability such as the 'e-recruitment' or 'e-training' of employees (Jayanti, 2012).

\subsubsection{Networking capability}

The networking capability is specific to the firm and indicates its ability to manage relationships with suppliers and other business partners (Human, and Naudé, 2009). In empirical research, the networking capability has been found to positively moderate the impact of explorative learning on competitive performance (Chung, Yang and Huang, 2015) and conversely, the networking capability has been found to positively mediate the impact of the learning capability on competitiveness (Husain, Dayan and Di Benedetto, 2016). As can be expected with the advent of Web-based technologies and Web 2.0 in particular, networking is a strategic capability that has been observed to gain most from a well-developed IT infrastructure (Barão, Braga de Vasconcelos, Rocha and Pereira, 2017), and in particular from an e-business capability such as the 'e-collaboration' between partners (Dong and Yang, 2015).

\subsection{Organizational outcomes of explorative learning: competitive performance}

Viewed as a dynamic capability, OL has been studied in the strategic management literature with regards to its direct and indirect effects on performance (Easterby-Smith and Prieto, 2008). Empirical studies have thus confirmed the positive impact of OL on the firm's organizational performance in general (López-Nicolás and Meroño-Cerdán, 2011; Ruiz-Jiménez and FuentesFuentes, 2013). In particular, past research has found a positive influence of OL on the firm's innovation performance (Liao, Chang, Hu and Yueh, 2012; Onăg, Tepeci and Başalp, 2014; 
Salunke, Weerawardena and McColl-Kennedy, 2019), and on its productivity (Deng, Doll and Cao, 2008). Furthermore, it has also been confirmed empirically that innovation in service enterprises has a positive effect on labour productivity (Deng et al., 2008; Peters, Riley, Siedschlag, Vahter and McQuinn, 2018). As a result, we focus in this study on innovation performance and productivity as being the two main dimensions of competitive performance.

\subsection{Organizational context of explorative learning: firm size}

In the services sector, firm size may be thought of as a proxy for certain aspects of the firm's organizational context, and for the abundance and availability of resources and competencies in particular, as smaller firms are generally found to be less endowed than larger firms in this regard (de Brentani, 1995; Nunes et al., 2010). Firm size constitutes a potentially important contingency for industrial service SMEs in developing their IT capabilities for exploration and their strategic capabilities for explorative learning (Hong and Oxley, 2016; Chikweche and Bressan, 2018). Thus, including firm size is important, even more so considering that the management literature has demonstrated the influence of organizational size differences on performance outcomes (Benito-Osorio, Colino, Guerras-Martín and Zúñiga-Vicente; Hong and Oxley, 2016; Hwang, Hwang and Dong, 2015).

\section{Methods}

\subsection{Sample}

This study's data were culled from a benchmarking database that contains information on 92 industrial service SMEs located in Quebec, Canada. These enterprises offer knowledge-based and high value-added services to the manufacturing industry, and in areas such as IT, human resources, R\&D and logistics. The database was created by having the firms' top executives and IT manager answer a twenty-page questionnaire to gather wide-ranging data on the competitive performance and business practices of their firm. In exchange for providing this 
data, the firms obtained a comparative diagnosis of their strategic situation and competitive position.

\subsection{Measures}

The sampled firms' IT and strategic capabilities were assessed with surrogate measures taken from the extant IS and strategic management literatures. The IT capability for exploration was assessed through the identification of the different organization's IT infrastructure and ebusiness capabilities. These two capabilities were measured with summative indices calculated from the number of IT-based and Web-based systems and applications such as rapid prototyping and e-business intelligence that are used by the firm mainly for explorative purposes (Zhu, 2004). The R\&D capability was assessed by the most commonly used proxy, namely the R\&D budget per employee (Barry, 2005). The SHRM capability was measured by assessing the mean level of development of ten high-performance HRM practices related to the recruitment, performance evaluation, remuneration, training, development, motivation and empowerment of employees (Uwizeyemungu et al., 2018). The networking capability was measured by the number of the firm's partnerships with other organizations in domains such as marketing, R\&D and service delivery (Raymond and St-Pierre, 2013). Innovation performance was assessed by a commonly used measure, i.e. the proportion of sales ascribed to new or modified services (Garcia and Calantone, 2002), whereas labour productivity was assessed with the financial measure most used by researchers and practitioners, i.e. the firm's gross profit per employee (Bryan, 2007). The measures containing the questionnaire items may be found in Appendix A.

\section{Results}


The research questions were answered by using fuzzy set qualitative comparative analysis (fsQCA), a method appropriate for small sample size (Rihoux and Ragin, 2009). This method uses Boolean algebra to identify different configurations of elements or causal conditions that are associated to the same preferred outcome (high levels of competitive performance in our case) (Ragin, 2008). Thus, the principal contribution of fsQCA lies in its ability to evaluate the relation between a configuration of elements and an outcome. Analysis of our configurational framework was preceded by a direct fuzzy set 'calibration' of the research variables, as it is recommended when Likert-type scales and indexes are used for variable measurement (Liu, Mezei, Kostakos and Li, 2017). For each of our research variables, we thus identified the three points of fuzzy set membership by using percentiles, as recommended in the fsQCA literature (Dul, 2016; Glaesser and Cooper, 2014; Plewa, Ho, Conduit and Karpen, $2016)^{1}$.

Presented in Table 1 are the descriptive statistics and fuzzy set calibration thresholds for causal variables or elements forming the configurations and for the outcome variables. We determined the threshold for being 'fully-in' to be the top quartile value across cases, the 'crossover' to be at the median value, and the bottom quartile value as the threshold to be 'fully-out'. We used the same thresholds for the preferred outcomes, i.e. the top quartile value both for 'high' innovation performance and 'high' productivity. Following the identification of the three threshold values for all research variables, the fsQCA procedure uses a nonlinear logistic function that transforms all cases of a variable into a fuzzy set, thus allowing cases to take a value between 0 and 1 (Liu et al., 2017; Ragin, 2008).

\footnotetext{
${ }^{1}$ Some of the variables are skewed as a result of the nature of some of the measures, and thus, data calibration was done using percentiles (Dul, 2016) because calibrating based on survey scales or indexes is likely to offer less meaningful results (Plewa et al., 2016).
} 
Table 1: Descriptive statistics and calibration of the research variables $(n=92)$

\begin{tabular}{|c|c|c|c|c|c|c|c|}
\hline \multirow{2}{*}{ Research Variable } & \multicolumn{3}{|c|}{$\begin{array}{c}\text { Fuzzy Set } \\
\text { Calibrations }\end{array}$} & \multirow{2}{*}{ mean } & \multirow{2}{*}{ s.d. } & \multirow{2}{*}{$\min$} & \multirow{2}{*}{$\max$} \\
\hline & $\begin{array}{l}\text { fully } \\
\text { in }\end{array}$ & $\begin{array}{c}\text { cross- } \\
\text { over }\end{array}$ & $\begin{array}{c}\text { fully } \\
\text { out }\end{array}$ & & & & \\
\hline \multicolumn{8}{|l|}{ Strategic Cap. for Explorative Learning } \\
\hline R\&D Capability ${ }^{\mathrm{a}}$ & 3000 & 500 & 0 & 4525 & 12352 & 0 & 69747 \\
\hline SHRM Capabilityb & 0.40 & -0.05 & -0.40 & 0.04 & 0.45 & -0.81 & 1.43 \\
\hline Networking Capability ${ }^{c}$ & 5 & 2 & 0 & 2.5 & 2.7 & 0 & 12 \\
\hline \multicolumn{8}{|l|}{ IT Capabilities for Exploration } \\
\hline e-Business Capability for Exploration ${ }^{\mathrm{d}}$ & 4 & 1 & 0 & 2.1 & 1.9 & 0 & 6 \\
\hline IT Infrastructure Cap. for Exploration ${ }^{\mathrm{e}}$ & 4 & 1 & 0 & 2.7 & 1.5 & 0 & 4 \\
\hline \multicolumn{8}{|l|}{ Competitive Performance } \\
\hline Innovation Performance ${ }^{f}$ & 0.30 & 0.05 & 0.00 & 0.18 & 0.30 & 0.00 & 1.00 \\
\hline Productivityg & 0.67 & 0.33 & 0.10 & 0.41 & 0.44 & -1.07 & 2.31 \\
\hline \multicolumn{8}{|l|}{ Organizational Context } \\
\hline Firm Size $^{\text {h }}$ & 40 & 25 & 10 & 31 & 27 & 4 & 146 \\
\hline \multicolumn{8}{|l|}{ a R\&D budget / number of employees (CAN \$) } \\
\hline \multirow{4}{*}{\multicolumn{8}{|c|}{$\begin{array}{l}{ }^{b} \text { mean level of development of } 10 \text { high-performance HRM practices (standardized variables) } \\
{ }^{c} \text { number of formal collaborations with customers, suppliers, consultants, universities and research centres } \\
{ }^{d} \text { number of explorative activities that are realized by the firm through e-business applications and the Web } \\
{ }^{e} \text { number of technologies and systems that are used by the firm for explorative purposes }\end{array}$}} \\
\hline & & & & & & & \\
\hline & & & & & & & \\
\hline & & & & & & & \\
\hline \multicolumn{8}{|l|}{${ }^{\mathrm{f}}$ sales of new or modified services / total sales } \\
\hline \multicolumn{8}{|c|}{$\mathrm{g}$ gross profit / number of employees (x $100000 \mathrm{CAN} \$$ ) } \\
\hline \multicolumn{8}{|c|}{${ }^{\mathrm{h}}$ number of employees } \\
\hline Nota. Calibration thresholds: fully in $=\mathrm{t}$ & & sso & $\mathrm{me}$ & & & & \\
\hline
\end{tabular}

The sampled firms' size varied from 4 to 146 employees with a mean of 31 and a median of 25. Most variables were not highly correlated except for e-business capability for exploring and IT infrastructure capability for exploring which presented the highest correlation $(-0.57)$, as presented in Table 2 .

The first step in fsQCA is the analysis of the configurational elements that are deemed 'necessary' for the outcome. As presented in Table 3, the necessity of an element or causal condition is assessed by its consistency, that is, by the extent to which members in this condition (e.g., firms having a strong SHRM capability), also show membership in the outcome (e.g., firms achieving a high level of productivity) (Ragin, 2006). Now, a causal condition is deemed to be necessary for an outcome when its consistency score is higher than 0.90 (Ragin, 
2008). Thus, as indicated in Table 3 , no configurational element was found to be individually necessary to achieve high innovation performance and high productivity.

Table 2: Inter-correlations of the research variables $(n=92)$

\begin{tabular}{|c|c|c|c|c|c|c|c|}
\hline \multirow[b]{2}{*}{ Research Variable } & \multicolumn{7}{|c|}{ inter-correlations } \\
\hline & 1. & 2. & 3. & 4. & 5. & 6. & 7. \\
\hline 1. Firm Size & - & & & & & & \\
\hline 2. R\&D Capability & -0.01 & - & & & & & \\
\hline 3. SHRM Capability & 0.11 & 0.26 & - & & & & \\
\hline 4. Networking Capability & 0.07 & 0.07 & 0.30 & - & & & \\
\hline 5. e-Business Capability for Exploration & -0.21 & 0.12 & 0.30 & 0.29 & - & & \\
\hline 6. IT Infrastructure Capability for Exploration & 0.20 & 0.11 & -0.20 & -0.10 & -0.57 & - & \\
\hline 7. Innovation Performance & -0.06 & 0.44 & 0.17 & 0.07 & 0.23 & -0.01 & - \\
\hline 8. Productivity & 0.00 & 0.28 & 0.22 & -0.02 & 0.04 & 0.02 & 0.09 \\
\hline
\end{tabular}

Table 3: Necessity analysis of the configurational elements

\begin{tabular}{|l|c|c|c|c|}
\hline \multirow{2}{*}{ Configurational element } & \multicolumn{2}{c|}{$\begin{array}{c}\text { High Innovation } \\
\text { Performance }\end{array}$} & \multicolumn{2}{c|}{ High Productivity } \\
\cline { 2 - 5 } & Consistency & Coverage & Consistency & Coverage \\
\hline Strategic Cap. for Explorative Learning \\
\hline R\&D Capability & 0.542 & 0.627 & 0.391 & 0.532 \\
SHRM Capability & 0.643 & 0.531 & 0.637 & 0.618 \\
Networking Capability & 0.572 & 0.520 & 0.540 & 0.576 \\
\hline IT Capabilities for Exploration & & & \\
\hline e-Business Capability for Exploration & 0.761 & 0.602 & 0.601 & 0.558 \\
IT Infrastructure Cap. for Exploration & 0.775 & 0.452 & 0.820 & 0.561 \\
\hline Organizational Context & 0.575 & 0.489 & 0.554 & 0.552 \\
\hline Firm Size
\end{tabular}

\subsection{Configurations for high innovation performance and high productivity}

While fsQCA is first described with regard to the relationship between the desired outcome and the case sets built for each causal condition (or configurational variable), the main advantage of this technique lies in its capacity to analyze relationships between configurations, i.e. between combinations of causal conditions and the outcome case set (Ragin, 2008). As the 
solution sets (or desired configurations) are built through Boolean addition of individual causal conditions, a condition's fuzzy set score indicates its degree of membership in the solution.

The fsQCA technique starts its configurational analysis by creating a truth table of $2^{k}$ rows, where each row represents a possible configuration combining $k$ individual causal conditions. This table is sorted on the basis of the frequency and consistency of each configuration, where frequency represents the number of observations for each possible configuration (Pappas, Giannakos and Sampson, 2019) while consistency estimates the proportion of configurations "consistent with the outcome" (Fiss, 2011, p. 402).

The fsQCA method allows one to analyze the configurational elements that, together, are 'sufficient' to produce the chosen outcomes (Ragin, 2008). This analysis also distinguishes 'core' conditions, that is, those found to strongly influence the outcome, from 'peripheral' conditions, those found to have a lesser influence and thus may be exchangeable (with other peripheral conditions) or even expendable (Fiss, 2011). This method was thus applied to two sets of configurations: one for high innovation performance and another one for high productivity. In demonstrating equifinality and as presented in Table 4, the results of the fsQCA analysis identify six causal configurations, i.e. two sets of configurational elements (or causal conditions) equally associated to high levels of innovation performance (HI1 and HI2) and four sets equally associated to high levels of productivity (HP1, HP2, HP3 and HP4). The overall solution coverage indicates the proportion of cases that are covered by all reported configurations, whereas the overall solution consistency assesses the degree to which capability configurations are subsets of the outcome (Ragin, 2006). In this study, the consistency cut-off point was set at 0.75 , a satisfactory level proposed by Ragin (2008) and the minimum frequency equal to 1, as recommended for small sample sizes (Ragin, 2006). 
The high-innovation performance configurations, HI1 and HI2, highlight the primary importance of strong R\&D and SHRM capabilities ('core' conditions) ${ }^{2}$ and the secondary importance of a strong IT infrastructure for exploration capability ('peripheral' condition) Also, HI1 applies to small-sized enterprises (i.e. 24 employees or less) but not to medium-sized enterprise (i.e. 25 employees or more), whereas HI2 adds a strong explorative e-business capability as a core condition and is irrespective of firm size ('immaterial' condition) 4

Table 4: Configurations for high innovation performance and productivity

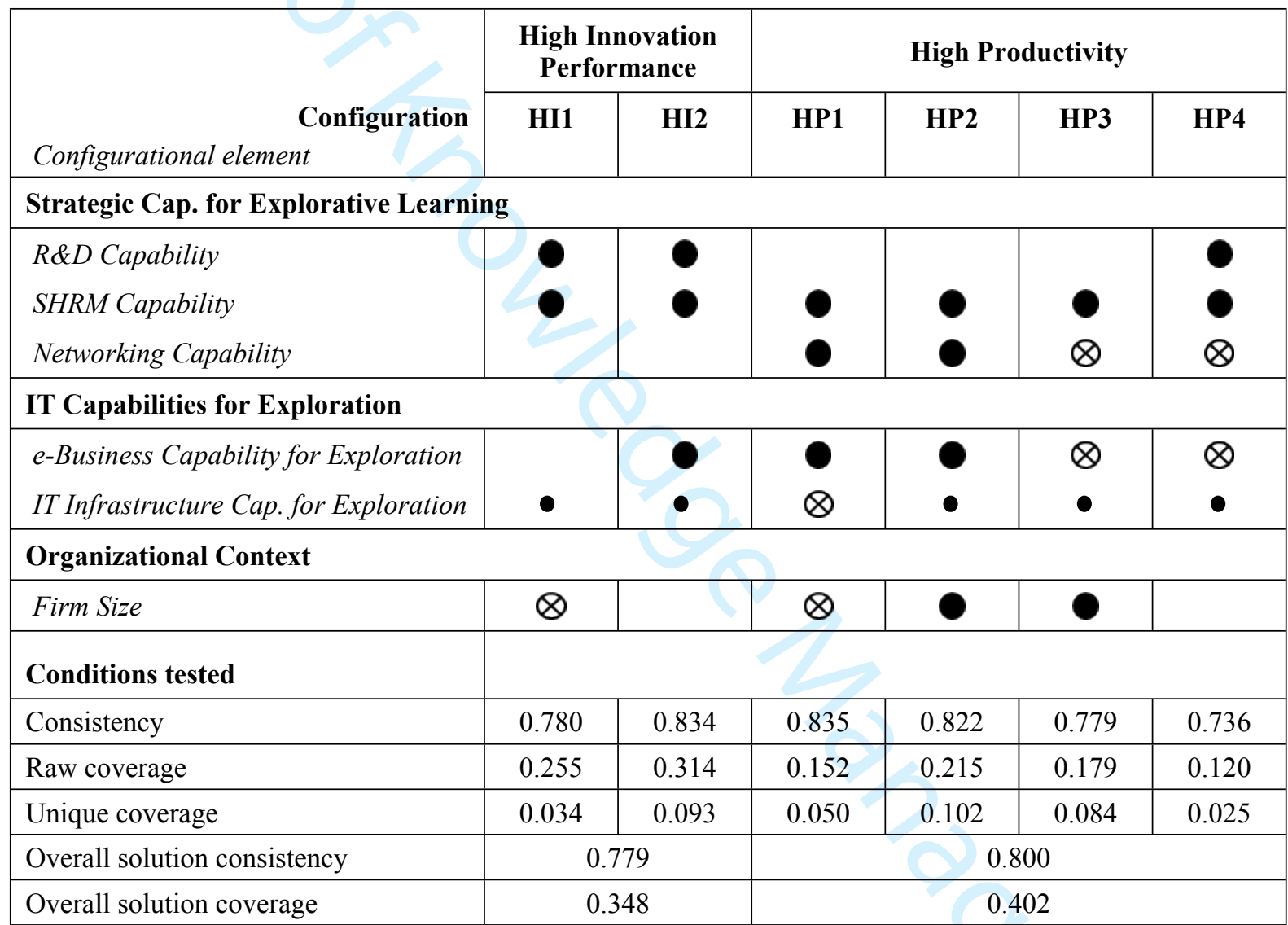

Legend.

$$
\begin{aligned}
& \bigotimes \text { : presence of a core condition } \\
& \bigotimes \text { : absence of a core condition } \\
& \text { blank: immaterial condition (“don't care") }
\end{aligned}
$$

\footnotetext{
${ }^{2}$ Core elements or conditions are those for which the evidence for a causal relationship with the outcome is strong (Fiss, 2011).

${ }^{3}$ Peripheral elements are those for which the evidence indicates a weak causal relationship with the outcome (Fiss, 2011).

${ }^{4}$ An immaterial condition represents a situation in which the element may be either present or absent without altering the causal relation between the configuration and the outcome (Ragin, 2008).
} 
The first two high-productivity configurations, HP1 and HP2, highlight the primary importance of having strong SHRM, networking and e-business capabilities. Furthermore, HP1 is under the condition that the firm does not have a strong IT infrastructure capability and applies to small-sized enterprises, whereas HP2 adds a strong IT infrastructure capability as a peripheral condition and applies to medium-sized enterprises. The last two high productivity configurations, HP3 and HP4, are characterized by the presence of a strong SHRM capability and the absence of strong networking and e-business capabilities as core conditions, as well as by the presence of a strong IT infrastructure capability as a peripheral condition. Also, HP3 applies to medium-sized enterprises, whereas HP4 requires a strong R\&D capability as a core condition and is irrespective of firm size.

\subsection{Configurations for non-high innovation performance and non-high productivity}

In addition to equifinality, the configurational approach taken here allows for causal asymmetry, i.e. the possibility that the causal conditions for the presence of the preferred outcome will differ from those for its absence (Fiss, 2011). As this approach allows for nonlinearity in causation, the same configurational element may thus have different causal roles within different configurations. In demonstrating causal asymmetry and as presented in Table 5, further results of the fsQCA analysis identify three causal configurations associated to nonhigh innovation performance and productivity, that is, to the absence - rather than the presence - of high levels of competitive performance. More precisely, results show two sets of causal configurations associated to non-high innovation performance (NHI1 and NHI2) and one set associated to non-high productivity (NHP1).

The two configurations associated to non-high innovation performance levels, NHI1 and $\mathrm{NHI}$, have two core conditions in common, i.e. firms in these configurations lack strong R\&D and explorative e-business capabilities. Also, NHI1 is characterized by the absence of a strong SHRM capability and applies to small-sized enterprises as core conditions, whereas NHI2 is 
characterized by the lack of a strong networking capability and applies to medium-sized firms as core conditions. The single configuration associated to the non-attainment of high productivity levels, NHP1, indicates the core conditions to be the absence of a strong SHRM capability as well as the presence of strong R\&D, networking and e-business capabilities, with the added peripheral condition that the firm be small-sized.

Table 5: Configurations for non-high innovation performance and productivity

\begin{tabular}{|c|c|c|c|}
\hline \multirow{2}{*}{ Configuration } & \multicolumn{2}{|c|}{$\begin{array}{c}\text { Non-High } \\
\text { Innovation Performance }\end{array}$} & \multirow{3}{*}{$\begin{array}{c}\begin{array}{c}\text { Non-High } \\
\text { Productivity }\end{array} \\
\text { NHP1 }\end{array}$} \\
\hline & \multirow[t]{2}{*}{ NHI1 } & \multirow[t]{2}{*}{ NHI2 } & \\
\hline & & & \\
\hline \multicolumn{4}{|l|}{ Strategic Cap. for Explorative Learning } \\
\hline$R \& D$ Capability & $\otimes$ & \multirow[t]{2}{*}{$\otimes$} & O \\
\hline SHRM Capability & $\otimes$ & & $\otimes$ \\
\hline Networking Capability & & $\otimes$ & 0 \\
\hline \multicolumn{4}{|l|}{ IT Capabilities for Exploration } \\
\hline e-Business Capability for Exploration & \multirow[t]{2}{*}{$\otimes$} & \multirow[t]{2}{*}{$\otimes$} & O \\
\hline IT Infrastructure Cap. for Exploration & & & \\
\hline \multicolumn{4}{|l|}{ Organizational Context } \\
\hline Firm Size & $\otimes$ & 0 & $\otimes$ \\
\hline \multicolumn{4}{|l|}{ Conditions tested } \\
\hline Consistency & 0.944 & 0.891 & 0.921 \\
\hline Raw coverage & 0.226 & 0.224 & 0.109 \\
\hline Unique coverage & 0.140 & 0.138 & 0.109 \\
\hline Overall solution consistency & \multicolumn{2}{|c|}{0.909} & 0.921 \\
\hline Overall solution coverage & \multicolumn{2}{|c|}{0.364} & 0.109 \\
\hline
\end{tabular}

Legend.

: presence of a core condition

$\otimes$ : absence of a core condition blank: immaterial condition ("don't care")

: presence of a peripheral condition

$\otimes:$ absence of a peripheral condition

\section{Discussion}

In answering the research question, a fsQCA analysis allowed us to unveil different capability configurations, that is, six causal 'recipes' that enable the explorative learning capability of industrial service enterprises to attain high levels of innovation performance and productivity. In line with the configurational approach, contingency theory and the $\mathrm{CBV}$, these equifinal 
configurations manifest a 'gestalts' type of alignment or 'fit' between the firms' IT capabilities for exploration and strategic capabilities for explorative learning (Raymond and St-Pierre, 2013). Hence, competitive performance was associate here to different capability configurations rather than being linearly predicted by each of its individual components, as it would be in the more traditional causal or 'path' analyses based on regression analysis or structural equation modelling (SEM) (Fiss, 2011).

With regard to the capability configurations unveiled, one first notes that the SHRM capability is present in all configurations of both high innovation performance and high productivity, and may thus be deemed as a 'necessary' condition (Dul, 2016), notwithstanding the results of the prior necessity analysis (Table 3$).{ }^{5}$ This means that explorative learning benefits the firm in terms of its competitive performance to the extent that employees are strongly motivated and empowered to undertake exploration activities. Another strategic capability that appears to be necessary to achieve high innovation performance is the R\&D capability. However, this capability appears in only one of the four high productivity configurations. This points to the industrial service firms' difficulty in being both highly innovative and highly productive at the same time, as these two outcomes are shown here to be achieved through very different capability configurations. One might also surmise that productivity, as opposed to innovation, would benefit more from exploitative rather than explorative learning, and in particular from IT capabilities for exploitation such as enterprise resource planning (ERP) systems and e-commerce applications.

With regards to the IT for exploration capabilities, a strong IT infrastructure is a peripheral rather than a core condition in the attainment of high innovation performance and high

\footnotetext{
${ }^{5}$ The necessity analyses reported in Table 3, indicate that the SHRM capability is not a necessary condition as its consistency is below the recommended threshold of 0.90 (Schneider and Wagemann, 2012). However, with such recommended threshold, false negatives or type II errors may occur (Dul, 2016). As a result, a second approach that might produce fewer false negatives (and positives) is to identify necessary conditions by selecting the conditions that are present in all configurations (Dul, 2016).
} 
productivity, that is, it must be present but is not 'determinant'. A strong e-business capability for exploration is also present in one of the two high innovation performance configurations and in two of four high productivity configurations as a core condition. In the high productivity case, the e-business capability appear to work in tandem with the networking capability, that is, when one is present the other is present as well (HP1 and HP2) and, conversely, when one is absent the other is also absent (HP3 and HP4). This would be an indication that a 'mismatch' between these two capabilities for explorative learning (i.e. a strong networking capability with a lack of e-business capability or vice-versa) would be detrimental to achieving high levels of productivity. This again points to the fact that by presuming IT capabilities to directly enable the firm's learning processes and to linearly assess their performance independently of other non-IT capabilities, as the traditional variance approach does, one is bound to have a more limited understanding of the true role and impact of these capabilities (Woodside, 2013). That is, our configurational approach and analytical technique (i.e. fsQCA) do not estimate the unique contribution of each condition for every resulting configuration; moreover, the configurational approach is not centered on estimating the 'net effects' of 'independent variables' on outcomes like the variance approach does. In contrast, fsQCA and the configurational approach view conditions (or 'independent variables') in combination, thus identifying the "connections of causally relevant conditions and outcomes" (Ragin, 2006, p. 8). As a result, the relation between organizational (IT and non-IT) capabilities and performance is viewed as being 'complex' and unexplainable by the simple direct effects afforded by the variance approach (Wang and Ahmed, 2007; Wilden, Devinney and Dowling, 2016). Thus, our study answers the calls for research on organizational capabilities and performance to take a configurational approach (Wilden et al., 2016).

\subsection{Contribution}


By viewing explorative learning as a dynamic capability that is enabled by the firm's IT and strategic capabilities, our study first contributes to OL theory by providing a more concrete or 'operational' grounding which allows for a greater practical applicability of this theory. By taking both the configurational view and the CBV of the OL-IT-performance causal framework, we were able to provide an empirical basis for unraveling, explaining and understanding the complex non-linear relationships embedded within this framework. This same approach may thus be used in future research to simultaneously investigate both explorative and exploitative IT and learning capabilities, that is, to focus on OL and IT ‘ambidexterity' (Benner and Tushman, 2015; Lee et al., 2015; March, 1991).

This study's results demonstrate that a fsQCA-based configurational approach is bettersuited theoretically to capture the complex, non-linear interplay between IT resources and nonIT resources (human resources most importantly) that supports the explorative learning process and thus, results in the competitive performance of industrial service firms (Wilden et al., 2016). Moreover, the strategic alignment of IT and strategic capabilities (such as SHRM capabilities) applied in this study provides us with a more powerful theoretical lens that may be used in future research on the antecedents and contingencies of these firms' learning and competitive behaviours (such as their strategic orientation and environmental uncertainty). This lens is also likely to provide a better understanding of the specific IT and organizational learning capabilities to be embedded into the digital transformation strategy of industrial service enterprises in facing new competitive challenges.

Our study also contributes to the OL, small business and IT literatures by emphasizing the learning aspects of the industrial service SME's capabilities development and the manner through which IT may contribute to this development (Andreu and Ciborra, 1996). By conceptually and operationally embedding IT and strategic capabilities for exploration into explorative learning capability configurations, we demonstrate how IT can become an active 
component of the firm's learning process and of its ensuing competitiveness (Kane and Alavi, 2007). Moreover, by conceptualizing and analyzing IT capabilities for exploration with two distinct constructs, we answer calls for studying such capabilities by capturing their ontological dimension (Ortiz de Guinea and Webster, 2013), that is, by uncovering their underlying 'IT artifact' (Robey et al., 2000). Our operationalization of IT capabilities for exploration captures specific and concrete IT infrastructure and e-business capabilities and thus constitutes a departure from prior operationalisations of IT capabilities that have generally utilized perceptual measures that do not identify the specific technologies nor the specific activities they enable such as sensing, learning and innovating (Lee et al., 2015). In so doing, we are also able to provide industrial service enterprises with actionable options for developing a capability configuration that, in coherence with their strategic posture, further enables their explorative learning processes and thus improves their competitive performance.

As another contribution, this study combines IT related capabilities (i.e., e-business and IT infrastructure capabilities for exploration) with other strategic capabilities (i.e., R\&D, networking, and SHRM capabilities) together and analyzes their joint effect on competitive performance. This contributes to the IT literature since most studies have explored the IT capability-performance link without including other organizational capabilities, while the reverse is true of most management studies with regard to the IT capabilities-performance link (Orlikowski, 2010; Zammuto, Griffith, Majchrzak, Dougherty and Faraj, 2007). Thus, our study answers the calls for further investigation of the interplay between OL, IT and other organizational capabilities as they affect the firm's performance (El Sawy, Malhotra, Park and Pavlou, 2010; Wilden et al., 2016).

In addition to its contribution to OL theory, our study also contributes to OL, small business and IT management practice. That is, our findings may provide managers of industrial service SMEs (and those who counsel and assist them) with different explorative learning capability 
configurations that may be emulated with the aim of enabling their explorative learning processes and improving in turn their competitive performance. Given the IT and non-IT resources at their disposal, these firms may envisage the learning capability configuration that best fits their specific business environment and organizational context, and best meets their aim for either improved innovation performance or improved productivity. And if the aim is to achieve overall competitive performance, that is, to achieve high-performance both in terms of innovation and productivity, industrial service SMEs should definitely invest in developing their e-business capability for exploration (HI2, HP1 and HP2), and do so in conjunction with the development of their SHRM capability, their networking capability and their R\&D capability.

As a further contribution to practice and in view of the causal asymmetry demonstrated in this study, our results indicate to managers the capability configurations that should be avoided, that is, those associated to the absence of either high service innovation performance or high productivity, or the absence of both. For instance, for small service enterprises, the lack of a strong SHRM capability would prevent them from attaining high levels of competitive performance, whatever the investment and the efforts made to develop their IT capabilities for exploration. Furthermore, as its explorative learning processes and mechanisms may be assessed by the firm in order to improve its competitive performance, the basis of its IT strategy would be to emulate those high-performing configurations that are coherent with its strategic objectives. Consequently, from an IT 'strategy-as-practice' perspective (Whittington, 2014), the configurational approach based on fsQCA analysis generates knowledge that is immediately and directly transferable, as opposed to the universalistic approach based on regression or SEM analyses, because the former analytical approach provides managers with equally-effective strategic options for the digital transformation of their firm whereas the latter approach cannot do so. 


\subsection{Limitations}

Our research has intrinsic limitations with regards to the generalization of its results, related to the survey method employed and to the nature and size of the sample. For instance, causality, as understood in the variance-based tradition, cannot be inferred as our study is cross-sectional and thus, the time-lagged effect of the firm's capability configuration upon its competitive performance is unascertainable. Moreover, the industrial service SMEs sampled here operate in sectors where knowledge requirements and technological intensity are rather high, whereas SMEs in all other service sectors are much more heterogeneous in this regard. Another limitation lies in the use of proxies to measure organizational capabilities, as such measures may not operationalize these capabilities with sufficient breadth and depth. Finally, our use of the fsQCA analytical method implies that choices made with regard to the research measures' calibration and other aspects (e.g. choosing the consistency threshold) may affect the study's results (Glaesser and Cooper, 2014). We nonetheless guarded as best we could against such potential arbitrariness in our results by conducting a sensitivity analysis that confirmed the stability of our configurational solutions across different calibrations (Fiss, 2011) and by using the fsQCA thresholds most recommended in the literature (e.g. consistency threshold of 0.75 ) (Dul, 2016).

\subsection{Conclusion}

A configurational approach allowed us to identify causal configurations that associate the explorative learning capabilities of industrial service firms to high levels of innovation performance and productivity. These configurations were characterized in terms of the firms' IT capabilities for exploration, strategic capabilities for explorative learning and firm size. In further empirical investigations of the organizational learning capability, future research could rather focus on exploitative learning in order to better help industrial service firms in dealing with the increasing complexity of their business environment. And by using a configurational 
approach to do so, future studies may add to our comprehension of how IT enables OL processes and mechanisms by further characterising the complex nature and impacts of the explorative and exploitative learning capability configurations developed by these firms in their pursuit of competitive performance.

\section{References}

Aboal, D. and Tacsir, E. (2018). Innovation and productivity in services and manufacturing: the role of ICT. Industrial and Corporate Change, Vol. 27, No. 1, pp. 221-241.

Ajamieh, A., Benitez, J., Braojos, J. and Gelhard, C, (2016). IT infrastructure and competitive aggressiveness in explaining and predicting performance. Journal of Business Research, Vol. 69, pp. 4667-4674.

Andreu, R. and Ciborra, C. (1996). Organisational learning and core capabilities development: the role of IT. Journal of Strategic Information Systems, Vol. 5, pp. 111-127.

Aral, S. and Weil, P. (2007). IT assets, organizational capabilities, and firm performance: how resource allocations and organizational differences explain performance variation. Organization Science, Vol. 18, No. 5, pp. 763-780.

Barão, A., Braga de Vasconcelos, J., Rocha, Á. and Pereira, R. (2017). A knowledge management approach to capture organizational learning networks. Strategic Management Journal, Vol. 24, pp. 737-740.

Barry, F. (2005). FDI, transfer pricing and the measurement of R\&D intensity. Research Policy, Vol. 34, pp. 673-681.

Beise-Zee, R. and Rammer, C. (2006). Local user-producer interaction in innovation and export performance of firms. Small Business Economics, Vol. 27, pp. 207-222.

Belderbos, R. (2003). Entry mode, organizational learning, and R\&D in foreign affiliates: Evidence from Japanese firms. Strategic Management Journal, Vol. 5, pp. 235-259.

Benito-Osorio, D., Colino, A., Guerras-Martín, L. A. and Zúñiga-Vicente, J. A. (2016). The internal diversification-performance link in Spain: Does firm size really matter? International Business Review, Vol. 25, No.2, pp. 548-558.

Benner, M.J. and Tushman, M.L. (2003). Exploitation, exploration, and process management: the productivity dilemma revisited. Academy of Management Review, Vol. 28, No. 2, pp. 238-256.

Benner, M.J. and Tushman, M.L. (2015). Reflections on the 2013 Decade Award "Exploration, exploitation, and process management: the productivity dilemma revisited" ten years later. Academy of Management Review, Vol. 40, No. 4, pp. 497-514-256.

Berta, W., Cranley, L., Dearing, J.W., Dogherty, E., Squires, J.E. and Estabrooks, C.A. (2015). Why (we think) facilitation works: insights from organizational learning theory. Implementation Science, Vol. 10, No. 141, pp. 1-13.

Bharadwaj, A.S. (2000). A resource-based perspective on information technology capability and firm performance: An empirical investigation. MIS Quarterly, Vol. 24, No. 1, pp. 169196.

Bharadwaj, A., El Sawy, O.A., Pavlou, P.A. and Venkatraman, N. (2013). Digital business strategy: toward a next generation of insights. MIS Quarterly, Vol. 37, No. 2, pp. 471-482.

Bhatnagar, J. (2007). Predictors of organizational commitment in India: strategic HR roles, organizational learning capability and psychological empowerment. International Journal of Human Resource Management, Vol. 18, pp. 1782-1811. 
Bresman, H. (2013). Changing routines: A process model of vicarious group learning in pharmaceutical R\&D. Strategic Management Journal, Vol. 56, No. 1, pp. 35-61.

Bryan, L.L. (2007). The new metrics of corporate performance: Profit per employee. McKinsey Quarterly, No. 1, pp. 56-65.

Bryson, J.R., Keeble, D. and Wood, P. (1997). The creation and growth of small business service firms in post-industrial Britain. Small Business Economics, Vol. 9, pp. 345-360.

Camps, J., Oltra, V., Aldás-Manzano, J., Buenaventura-Vera, G. and Torres-Carballo, F. (2016). Individual performance in turbulent environments: The role of organizational learning capability and employee flexibility. Human Resource Management, Vol. 55, No. 3, pp. 363-383.

Chikweche, T. and Bressan, A. (2018). A systematic review of future research challenges and prospects of organizational learning research in small medium size enterprises. Journal of Small Business \& Entrepreneurship, Vol. 30, No. 2, pp. 175-191.

Chung, H.F.L., Yang, Z. and Huang, P.-H. (2015). How does organizational learning matter in strategic business performance? The contingency role of guanxi networking. Journal of Business Research, Vol. 68, pp. 1216-1224.

Croasdell, D.T. (2001). IT's role in organizational memory and learning. Information Systems Management, Vol. 18, No. 1, pp. 8-11.

de Brentani, U. (1995). Firm size: Implications for achieving success in new industrial services. Journal of Marketing Management, Vol. 11, pp. 207-225.

Delery, J.E. and Doty, D.H. (1996). Modes of theorizing in strategic human resource management: tests of universalistic, contingency and configurational performance predictions. Academy of Management Journal, Vol. 39, pp. 802-35.

Desarbo, W.S., Di Benedetto, C.A., Song, M. and Sinha, I. (2005). Revisiting the Miles and Snow strategic framework: uncovering interrelationships between strategic types, capabilities, environmental uncertainty, and firm performance. Strategic Management Journal, Vol. 26, No. 1, pp. 47-74.

Deng, X., Doll, W.J. and Cao, M. (2008). Exploring the absorptive capacity to innovation/productivity link for individual engineers engaged in IT enabled work. Information \& Management, Vol. 45, pp. 75-87.

Di Benedetto, C.A., DeSarbo, W.S. and Song, M. (2008). Strategic capabilities and radical innovation: An empirical study in three countries. IEEE Transactions on Engineering Management, Vol. 55, No. 3, pp. 420-433.

Dixon, S.E.A., Meyer, K.E. and Day, M. (2007). Exploitation and exploration learning and the development of organizational capabilities: A cross-case analysis of the Russian oil industry. Human Relations, Vol. 60, No. 10, pp. 1493-1523.

Dong, J.Q. and Yang, C.-H. (2015). Information technology and organizational learning in knowledge alliances and networks: Evidence from U.S. pharmaceutical industry. Information \& Management, Vol. 52, pp. 111-122.

Doty, D.H., Glick, W.H. and Huber, G.P. (1993). Fit, equifinality, and organizational effectiveness: A test of two configurational theories. Academy of Management Journal, Vol. 36, No. 6, pp. 1196-1250.

Dul, J. (2016). Identifying single necessary conditions with NCA and fsQCA. Journal of Business Research, Vol. 69, No. 4, pp. 1516-1523.

Easterby-Smith. M. and Prieto, I.M. (2008). Dynamic capabilities and knowledge management: an integrative role for learning? British Journal of Management, Vol. 19, pp. 235-249.

El Sawy, O.A., Malhotra, A., Park, Y.K. and Pavlou, P.A. (2010). Seeking the configurations of digital ecodynamics: It takes three to tango. Information Systems Research, Vol. 21, No. 4, pp. 835-848. 
Fabi, B., Lacoursière, R., Raymond, L. and St-Pierre, J. (2010). HRM capabilities as a determinant and enabler of productivity for manufacturing SMEs. Human Systems Management, Vol. 29, No. 3, pp. 115-123.

Fink, L., Yogev, N. and Even, A. (2017). Business intelligence and organizational learning: An empirical investigation of value creation processes. Information \& Management, Vol. 54, pp. 38-56.

Fiss, P. (2011). Building better causal theories: A fuzzy set approach to typologies in organization research. Academy of Management Journal, Vol. 54, No. 2, pp. 393-420.

Garcia, R. and Calantone, R. (2002). A critical look at technological innovation typology and innovativeness terminology: a literature review. Journal of Product Innovation Management, Vol. 19, pp. 110-132.

Glaesser, J. and Cooper, B. (2014). Exploring the consequences of a recalibration of causal conditions when assessing sufficiency with fuzzy set QCA. International Journal of Social Research Methodology, Vol. 17, No. 4, pp. 387-401.

Grant, R.M. (1996). Prospering in dynamically-competitive environments: organizational capability as knowledge integration. Organization Science, Vol. 7, No. 4, pp. 375-387.

Gresov, C. and Drazin, R. (1997). Equifinality: functional equivalence in organizational design. Academy of Management Journal, Vol. 22, No. 2, pp. 431-452.

Grewal, R, and Slotegraaf, R.J. (2007). Embeddedness of organizational capabilities. Decision Sciences, Vol. 38, No. 3, pp. 451-488.

Hassid, J. and Fafaliou, I. (2006). Internationalisation and human resources development in European small firms, Production Planning \& Control, Vol. 17. No. 3, 247-256.

Hill, J. and Scott, T. (2004). A consideration of the roles of business intelligence and e-business in management and marketing decision making in knowledge-based and high-tech startups, Qualitative Market Research: An International Journal, Vol. 7, No. 1, pp. 48-57.

Hine, M.J. and Goul, M. (1998). The design, development, and validation of a knowledgebased organizational learning support system. Journal of Management Information Systems, Vol. 15, No. 2, pp. 119-152.

Hong, S. and Oxley, L. (2016). Why firm size matters: Investigating the drivers of innovation and economic performance in New Zealand using the Business Operations Survey. Applied Economics, Vol. 48, No. 55, pp. 1-17.

$\mathrm{Hu}, \mathrm{H}$., Wu, J. and Shi, J. (2016). Strategic HRM and organisational learning in the Chinese private sector during second-pioneering. International Journal of Human Resource Management, Vol. 27, No. 16, pp. 1813-1832.

Human, G. and Naudé, P. (2009). Exploring the relationship between network competence, network capability and firm performance: a resource-based perspective in an emerging economy. Management Dynamics, Vol. 18, No. 1, pp. 2-14.

Husain, Z., Dayan, M. and Di Benedetto, C.A. (2016). The impact of networking on competitiveness via organizational learning, employee innovativeness, and innovation process: A mediation model. Journal of Engineering and Technology Management, Vol. 40, No. 1, pp. 15-28.

Hutton, S. and Eldridge, S. (2019). Improving productivity through strategic alignment of competitive capabilities. International Journal of Productivity and Performance Management, Vol. 68, No. 3, pp. 644-668.

Hwang, Y.S., Hwang, M.H. and Dong, X. (2015). The relationships among firm size, innovation type, and export performance with regard to time spans. Emerging Markets Finance \& Trade, Vol. 51 No. 5, pp. 947-962.

Janson, M., Cecez-Kecmanovic, D. and Zupančič, J. (2007). Prospering in a transition economy through information-technology-supported organizational learning. Information Systems Journal, Vol. 17, pp. 3-36. 
Jayanti, E. (2012). Open sourced organizational learning: implications and challenges of crowdsourcing for human resource development (HRD) practitioners. Human resource Development International, Vol. 15, No. 3, pp. 375-384.

Joshi, K.D., Chi, L., Datta, A. and Han, S. (2010). Changing the competitive landscape: Continuous innovation through IT-enabled knowledge capability. Information Systems Research, Vol. 21, No. 3, pp. 472-495.

Kane, G.C. and Alavi, M. (2007). Information technology and organizational learning: An investigation of exploration and exploitation processes. Organization Science, Vol. 18, No. 5, pp. 796-812.

Khatri, N. (2006). Building HR capability in health care organizations. Health Care Management Review, Vol. 31, No. 1, pp. 45-54.

Khatri, N., Baveja, A., Agrawal, N.M. and Brown, G.D. (2010). HR and IT capabilities and complementarities in knowledge-intensive services. International Journal of Human Resource Management, Vol. 21, No. 15, pp. 2889-2909.

Khedaouria, A., Montani, F. and Thurik, R. (2017). Time pressure and team member creativity within R\&D projects: The role of learning orientation and knowledge sourcing. International Journal of Project Management, Vol. 35, pp. 942-954.

Koschatsky, K. and Stahlecker, T. (2010). The emergence of new modes of R\&D services in Germany. The Service Industries Journal, Vol. 30, No. 5, pp. 685-700.

Kroon, B., Van De Voorde, K. and Timmers, J. (2013). High performance work practices in small firms: a resource-poverty and strategic decision-making perspective. Small Business Economics, Vol. 41, No. 1, pp. 71-91.

Lee, O.-K., Sambamurthy, V., Lim, K. H. and Wei, K. K. (2015). How does IT ambidexterity impact organizational agility? Information Systems Research, Vol. 26, No.2, pp. 398-417.

Lee, M.T. and Widener, S.K. (2016). The performance effects of using business intelligence systems for exploitation and exploration learning. Journal of Information Systems, Vol. 30, No. 3, pp. 1-31.

Levinthal, D.A. and March, J.G. (1993). The myopia of learning. Strategic Management Journal, Vol. 14, pp. 95-112.

Li, Y.-H. and Huang, J.-W. (2013). Exploitative and exploratory learning in transactive memory systems and project performance. Information \& Management, Vol. 50, No. 6, pp. 304-313.

Liao, S.-H., Chang, W.-J., Hu, D.-C. and Yueh, Y.-L. (2012). Relationships among organizational culture, knowledge acquisition, organizational learning, and organizational innovation in Taiwan's banking and insurance industries. International Journal of Human Resource Management, Vol. 23, No. 1, pp. 52-70.

Liu, H., Ke, W., Wei, K.K. and Hua, Z. (2013). The impact of IT capabilities on firm performance: The mediating roles of absorptive capacity and supply chain agility. Decision Support Systems, Vol. 54, No. 3, pp. 1452-1462.

Liu, Y., Mezei, J., Kostakos, V. and Li, H. (2017). Applying configurational analysis to IS behavioural research: a methodological alternative for modelling combinatorial complexities. Information Systems Journal, Vol. 27, No. 1, pp. 59-89.

López-Nicolás, C. and Meroño-Cerdán, Á.L. (2011). Strategic knowledge management, innovation and performance. International Journal of Information Management, Vol. 31, pp. 502-509.

Lucena, A. and Roper, S. (2016). Absorptive capacity and ambidexterity in R\&D: Linking technology alliance diversity and firm innovation. European Management Review, Vol. 13, pp. 159-178.

March, J.G. (1991). Exploration and exploitation in organizational learning. Organization Science, Vol. 2, No. 1, pp. 71-87. 
Martínez-Senra, A.I., Quintás, M.A., Sartal, A. and Vázquez, X.H. (2015). How can firms' basic research turn into product innovation? The role of absorptive capacity and industry appropriability. IEEE Transactions on Engineering Management, Vol. 62, No. 2, pp. 205216.

Miller, D., Eisenstat, R. and Foote, N. (2002). Strategy from the inside out: Building capabilitycreating organizations. California Management Review, Vol. 44, No. 3, pp. 37-54.

$\mathrm{Mu}$, J. and Di Benedetto, A. (2012). Networking capability and new product development. IEEE Transactions on Engineering Management, Vol. 9, No. 1, pp. 4-19.

Nguyen, T.N.Q., Ngo, L.V., Northey, G. and Siaw, C.A. (2019). Realising the value of knowledge resources and capabilities: an empirical study. Journal of Knowledge Management, Vol. 23, No. 2, 374-395.

Nielsen, J.A., Mathiassen, L. and Hansen, A.M. (2018). Exploration and exploitation in organizational learning: A critical application of the 4I model. British Journal of Management, Vol. 29, pp. 835-850.

Nunes, P.M., Serrasqueiro, Z., Mendes, L. and Sequeira, T.N. (2010). Relationship between growth and R\&D intensity in low-tech and high-tech Portuguese service SMEs. Journal of Service Management, Vol. 21, No. 3, pp. 291-320.

Oltra, V. and Vivas-López, S. (2013). Boosting organizational learning through team-based talent management: what is the evidence from large Spanish firms?. International Journal of Human Resource Management, Vol. 24, No. 9, pp. 1853-1871.

Onağ, A.O., Tepeci, M. and Başalp, A.A. (2014). Organizational learning capability and its impact on firm innovativeness. Procedia - Social and Behavioral Sciences, Vol. 150, pp. 7708-717.

Orlikowski, W.J. (2010). The sociomateriality of organizational life: Considering technology in management research. Cambridge Journal of Economics, Vol. 34, No. 1, pp. 125-141.

Ortiz de Guinea, A. and Webster, J. (2013). An investigation of information systems use patterns: Technological events as triggers, the effects of time, and consequences for performance. MIS Quarterly, Vol. 37, No. 4, pp. 1165-1188.

Park, Y., El Sawy, O.A. and Fiss, P.C. (2017). The role of business intelligence and communication technologies in organizational agility: A configurational approach. Journal of the Association for Information Systems, Vol. 18, No. 9, pp. 648-686.

Pavlou, P.A. and El Sawy, O.A. (2011). Understanding the elusive black box of dynamic capabilities. Decision Sciences, Vol. 42, No. 1, pp. 239-273.

Pentland, B.T. (1995). Information systems and organizational learning: The social epistemology of organizational knowledge systems. Accounting, Management and Information Technologies, Vol. 5, No. 1, pp. 1-21.

Peters, B., Riley, R., Siedschlag, J., Vahter, P. and McQuinn, J. (2018). Internationalisation, innovation and productivity in services: evidence from Germany, Ireland and the United Kingdom. Review of World Economics, Vol. 154, No. 3, pp. 585-615.

Plewa, C., Ho, J., Conduit, J. and Karpen, I.O. (2016). Reputation in higher education: A fuzzy set analysis of resource configurations. Journal of Business Research, Vol. 69, No. 8, pp. 3087-3095.

Popova-Nowak, I.V. and Cseh, M. (2015). The meaning of organizational learning: a metaparadigm perspective. Human Resource Development Review, Vol. 14, No. 3, pp. 299-331.

Prajogo, D. and Olhager, J. (2012). Supply chain integration and performance: The effects of long-term relationships, information technology and sharing, and logistics integration, International Journal of Production Economics, Vol. 135, pp. 514-522.

Qi, C. and Chau, P.Y.K. (2018). Will enterprise social networking systems promote knowledge management and organizational learning? An empirical study. Journal of Organizational Computing and Electronic Commerce, Vol. 28, No. 1, pp. 31-57. 
Ragin, C.C. (2006). Set relations in social research: Evaluating their consistency and coverage. Political Analysis, Vol. 14, No. 3, pp. 291-310.

Ragin, C.C. (2008). Redesigning social inquiry: Fuzzy sets and beyond, University of Chicago Press, Chicago.

Raymond, L., Bergeron, F., Croteau, A.-M. and St-Pierre, J. (2016). IT-enabled knowledge management for the competitive performance of manufacturing SMEs: An absorptive capacity-based view. Knowledge and Process Management, Vol. 23, No. 2, pp. 110-123.

Raymond, L. and Blili, S. (2000). Organizational learning as a foundation of electronic commerce in the network organization. International Journal of Electronic Commerce, Vol. 5, No. 2, pp. 29-45.

Raymond, L. and St-Pierre, J. (2013). Strategic capability configurations for the internationalization of SMEs: A study in equifinality. International Small Business Journal, Vol. 31, No. 1, pp. 82-102.

Real, J.C., Leal, A. and Roldán, J.L. (2006). Information technology as a determinant of organizational learning and technological distinctive competencies. Industrial Marketing Management, Vol. 35, pp. 505-521.

Rihoux, B. and Ragin, C. (2009) Configurational comparative methods: Qualitative comparative analysis (QCA) and related techniques, Sage Publications, Thousand Oaks, California.

Robey, D., Boudreau, M.-C. and Rose, G.M. (2000). Information technology and organizational learning: a review and assessment of research. Accounting, Management and Information Technologies, Vol. 10, pp. 125-155.

Ross, J.W. (2003). Creating a strategic IT architecture competency: learning in stages. MIS Quarterly Executive, Vol. 2, No. 1, pp. 31-43.

Ruiz-Jiménez, J.M. and Fuentes-Fuentes, M. (2013). Knowledge combination, innovation, organizational performance in technology firms. Industrial Management \& Data Systems, Vol. 113, No. 4, pp. 523-540.

Salunke, S., Weerawardena, J. and McColl-Kennedy, J.R. (2019). The central role of knowledge integration capability in service innovation-based competitive strategy. Industrial Marketing Management, Vol. 76, pp. 144-156.

Schlagwein, D. and Bjørn-Andersen, N. (2014). Organizational learning with crowdsourcing: The revelatory case of LEGO. Journal of the Association for Information Systems, Vol. 15, Special Issue, pp. 754-778.

Schneider, C.Q. and Wagemann, C. (2012). Set-theoretic methods for the social sciences: A guide to qualitative comparative analysis, Cambridge University Press, Cambridge, United Kingdom.

Setia, P., Venkatesh, V. and Joglekar, S. (2013). Leveraging digital technologies: how information quality leads to localized capabilities and customer service performance. MIS Quarterly, Vol. 37, No. 2, pp. 565-590.

Soto-Acosta, P., Popa, S. and Martinez-Conesa, I. (2018). Information technology, knowledge management and environmental dynamism as drivers of innovation ambidexterity: a study in SMEs. Journal of Knowledge Management, Vol. 22, No. 4, pp. 931-948.

Sun, P.Y.T. and Anderson, M.H. (2010). An examination of the relationship between absorptive capacity and organizational learning, and a proposed integration. International Journal of Management Reviews, Vol. 12, No. 2, pp. 130-150.

Teece, D., Peteraf, M. and Leih, S. (2016). Dynamic capabilities and organizational agility: Risk, uncertainty, and strategy in the innovation economy. California Management Review, Vol. 58, No. 4, 13-35.

Teece, D. J., Pisano, G. and Shuen, A. (1997). Dynamic capabilities and strategic management. Strategic Management Journal, Vol. 18, No. 7, pp. 509-533. 
Ulubasoglu, M.A., Akdis, M. and Kök, S.B. (2009). Internationalization and alliance formation: Evidence from Turkish SMEs, International Small Business Journal, Vol. 27, No. 3, 337-358.

Un, C.A. and Rodríguez, A. (2018). Learning from R\&D outsourcing vs. learning by R\&D outsourcing. Technovation, Vol. 72, pp. 24-33.

Uwizeyemungu, S., Raymond, L., Poba-Nzaou, P. and St-Pierre, J. (2018). The complementarity of IT and HRM capabilities for competitive performance: a configurational analysis of manufacturing and industrial service SMEs. Enterprise Information Systems, Vol. 12, No. 10, pp. 1336-1358.

von Zedtwitz, M. (2002). Organizational learning through post-project reviews in R\&D. $R \& D$ Management, Vol. 32, Vol. 3, pp. 255-268.

Wang, C. L. and Ahmed, P.K. (2007). Dynamic capabilities: A review and research agenda. International Journal of Management Reviews, Vol. 9, No. 1, pp. 31-51.

Whittington, R. (2014). Information systems strategy and strategy-as-practice: A joint agenda. Journal of Strategic Information Systems, Vol. 23, No. 1, pp. 87-91.

Wilden, R., Devinney, T.M. and Dowling, G.R. (2016). The architecture of dynamic capability research: Identifying the building blocks of a configurational approach. The Academy of Management Annals, Vol. 10, No. 1, pp. 997-1076.

Woodside, A.G. (2013). Moving beyond multiple regression analysis to algorithms: Calling for adoption of a paradigm shift from symmetric to asymmetric thinking in data analysis and crafting theory. Journal of Business Research, Vol. 66, No. 4, pp. 463-472.

Zahra, S.A. and George, G. (2002). The net-enabled business innovation cycle and the evolution of dynamic capabilities. Information Systems Research, Vol. 13, No. 2, pp. 147150.

Zammuto, R., Griffith, T.L., Majchrzak, A., Dougherty, D. and Faraj, S. (2007). Information technology and the changing fabric of organization. Organization Science, Vol. 18, No. 5, pp. 749-762.

Zhu, K. (2004). The complementarity of information technology infrastructure and ecommerce capability: A resource-based assessment of their business value. Journal of Management Information Systems, Vol. 21, No. 1, pp. 167-202. 


\section{Appendix A: Elements of the questionnaire designed to measure the research variables}

\begin{tabular}{|c|c|c|c|c|c|}
\hline & Managers & $\begin{array}{l}\text { Professionals/ } \\
\text { Technicians }\end{array}$ & $\begin{array}{r}\text { Operations } \\
\text { personnel }\end{array}$ & $\begin{array}{c}\text { Sales } \\
\text { personnel }\end{array}$ & $\begin{array}{r}\text { Clerical } \\
\text { personnel }\end{array}$ \\
\hline \multicolumn{6}{|l|}{ Integration } \\
\hline Recruitment policy & $\square$ & $\square$ & $\square$ & $\square$ & $\square$ \\
\hline Performance appraisal & $\square$ & $\square$ & $\square$ & $\square$ & $\square$ \\
\hline Health insurance program & $\square$ & $\square$ & $\square$ & $\square$ & $\square$ \\
\hline Employee health program & $\square$ & $\square$ & $\square$ & $\square$ & $\square$ \\
\hline Pension fund & $\square$ & $\square$ & $\square$ & $\square$ & $\square$ \\
\hline \multicolumn{6}{|l|}{ Remuneration } \\
\hline Stock ownership plan & $\square$ & $\square$ & $\square$ & $\square$ & $\square$ \\
\hline Profit sharing plan & $\square$ & $\square$ & $\square$ & $\square$ & $\square$ \\
\hline $\begin{array}{l}\text { Individual compensation } \\
\text { (e.g. bonuses) }\end{array}$ & & $\square$ & $\square$ & $\square$ & $\square$ \\
\hline
\end{tabular}

SHRM capability - Information

Indicate the categories of employees to which the following types of information are diffused.

Level of diffusion CEO/Board Managers/ Professionals/ Technicians/ of directors Dept. heads Sales personnel Clerical

Types of information diffused

Owners' vision of the firm's development

Firm's mission and strategic objectives

Financial results of the firm

Objectives in matters of innovation

Organizational and technological changes

Evolution of customer base

Customers' present and future needs

Competitors' threats and strategies

Market situation and its impact on the firm

Supervisors' expectations

\section{SHRM capability - Participation}

When a decision is taken concerning the organization and the realization of strategic activities (e.g. the adoption of a new technology, the improvement of product/service quality), employees are generally: (check a single box per line)

\begin{tabular}{|c|c|c|c|c|}
\hline Level of participation & $\begin{array}{l}\text { Informed of } \\
\text { the decision } \\
\text { taken }\end{array}$ & $\begin{array}{l}\text { Informed prior } \\
\text { to the } \\
\text { decision }\end{array}$ & $\begin{array}{l}\text { Consulted to } \\
\text { obtain } \\
\text { their advice }\end{array}$ & $\begin{array}{cc}\text { Copartners } & \text { Mandated } \\
\text { in the } & \text { to take the } \\
\text { decision } & \text { decision }\end{array}$ \\
\hline
\end{tabular}

Categories of employees

Managers

Professionals/Technicians

Operations personnel

Sales personnel

Clerical personnel 


\section{Networking Capability}

Please indicate the extent of your firm's formal collaborations with various organizations in terms of the domains of collaboration and the type of partners.

Partners $\begin{gathered}\text { Manufacturing } \\ \text { customers }\end{gathered}$
$\begin{gathered}\text { Non-manufact. Universities/ Consultants } \\ \text { customers colleges }\end{gathered}$ $\begin{array}{r}\begin{array}{r}\text { Suppliers } \\ \text { Research } \\ \text { centers }\end{array}\end{array}$

Collaboration domains

Personnel training

Service delivery

Purchasing/procurement

Design/R\&D

Marketing/sales

Improvements in service

and delivery process

\section{IT Infrastructure Capability for Exploration}

Please check if your firm uses any of the following technologies and systems.

CAD / CAM (computer-aided drafting, design and manufacturing)

Modeling / Simulation

Rapid Prototyping

Customer Relationship Management (CRM)

Mobile Communication (e.g. mobile computing, smartphone)

\section{e-Business Capability for Exploration}

Among the following activities, indicate those realized by your firm through e-business applications, the Internet and the Web.

e-Business intelligence

Prospecting for new customers in Canada

Prospecting for new customers abroad

Developing business intelligence

e-Collaboration

Interacting with customers to improve products/services

Interacting with business partners to design new products/services

e-HRM

Recruiting personnel 